\title{
Estimation of starvation and diel variation of the RNA/DNA ratios in field-caught Sardina pilchardus larvae off the north of Spain
}

\author{
M. Alexandra Chícharo ${ }^{1, *}$, Luis Chícharo ${ }^{1}$, Luis Valdés ${ }^{2}$, Eduardo López-Jamar ${ }^{3}$, \\ Pedro Ré ${ }^{4}$
}

\author{
${ }^{1}$ UCTRA, Universidade do Algarve, Campus de Gambelas, P-8000 Faro, Portugal \\ ${ }^{2}$ Instituto Español de Oceanografia, Promontorio de San Martín, s/n, E-39004 Santander, Spain \\ ${ }^{3}$ Instituto Espan̄ol de Oceanografia, Avda. De Brasil, 31, E-28020 Madrid, Spain \\ ${ }^{4}$ Lab. Mar. Guia, Fac. Ciências da Universidade de Lisboa, Est. do Guinelio, P-2750 Cascais, Portugal
}

\begin{abstract}
The aim of this study was to analyse the general larval condition, to determine the incidence of starvation and to investigate the effect of time of day on RNA/DNA ratios among field-caught Sardina pilchardus (L.) larvae. The larvae were collected during 4 research cruises off northern Spain, during March. April, May and June 1992. A highly sensitive fluorometric method for nucleic acid quantification was applied to larvae of $S$. pilchardus. The means of the RNA/DNA ratio were relatively high, so the larvae collected off northern Spain were generally in good condition. Low percentages of starving larvae (RNA/DNA ratio less than 1.3), ranging from 0 to $3.23 \%$, were found over the 4 mo. The RNA/DNA ratios were significantly correlated with zooplankton biomass. Larvae collected at night revealed higher RNA/DNA ratios compared to larvae caught during the day. This seems to indicate that there is some endogenous rhythm in the production of RNA. It would then follow that, if there are diel changes in RNA concentrations, average RNA indices can be unrepresentative if there is any day/night bias in sampling
\end{abstract}

KEY WORDS: Fish larvae $\cdot$ RNA/DNA - Sardina pilchardus - Starvation · Diel variation

\section{INTRODUCTION}

Sardina pilchardus is the basis of an important pelagic fishery on the Atlantic coast of the Iberian Peninsula (Pestana 1989). The annual recruitment to sardine stocks shows a high variability that may be reflected in overall stock abundance, thus affecting the fishery (Porteiro et al. 1986, Robles et al. 1992). It is commonly assumed that to understand recruitment variability it is necessary to study the factors which determine survival during the planktonic early life-history stages.

Many studies have confirmed that food availability is a limiting factor for survival during these early phases (Setzler-Hamilton et al. 1987). Cushing (1995) noted that the relationship between food level and survival is equivocal. Leggett \& Deblois (1994) have shown recent

•E-mail: mchicharo@ualg.pt evidence which suggests that failure to distinguish between zooplankton abundance and food availability for fish larvae may have compromised the evaluation of the importance of starvation on wild populations.

Several hypotheses - e.g. Hjort's (1914) 'critical period' hypothesis, Cushing's (1975, 1990) 'matchmismatch' hypothesis, and Lasker's (1975) 'stable ocean' hypothesis-link low fish larvae survival (and future recruitment) with starvation during the larval stage. Such relationships may be relatively simple to test in laboratory feeding experiments, but until recently they were difficult to demonstrate for sea-caught larvae. This situation has changed due to the introduction of condition indices, such as the RNA/DNA ratio, that make it possible to assess starvation in the ocean

Accurate assessment of larvae condition provides a means to study the significance of the biotic and abiotic factors affecting fish populations during the 
critical planktonic stage (Suthers et al. 1996). RNA/ DNA ratios have been used to assess the nutritional condition of a wide range of marine organisms, predominantly fish larvae (Buckley 1984, Robinson \& Ware 1988, Suthers 1992, Bailey et al. 1995). This index is based on the assumption that the amount of deoxyribonucleic acid (DNA), the primary carrier of genetic information, is stable under changing environmental situations, while the amount of ribonucleic acid (RNA), which is directly involved in protein synthesis, is affected by the nutritional condition of the organism. The RNA/DNA ratio is therefore susceptible to changes in the environment which affect the physiology of the organism, e.g. low prey availability (McGurk et al. 1992. Chícharo \& Chícharo 1995). Larvae in good condition tend to have a higher RNA/DNA ratio than those in poorer condition (e.g. Robinson \& Ware 1988, Clemmesen 1994, Chícharo 1996). It has been reported that this ratio can respond quickly to changes in environmental conditions (Martin \& Wright 1987), and this ratio has been used to give a measure of instantaneous growth in the field, in order to avoid periodic measuremenis (Buckiey 1984, Clàrke et al. 1989).

To assess starvation it is necessary to determine the RNA/DNA ratio below which larvae will be classified as starving. The idea of 'critical ratio' was originally discussed by Robinson \& Ware (1988) and is based on a model of the general relationship between the RNA/DNA ratio, temperature and protein growth rate as determined and reported by Buckley (1984). Robinson \& Ware (1988) defined the 'critical ratio' as the RNA/DNA ratio of a marine animal when the larval protein growth rate is zero. They calculated the 'critical ratio' for Pacific herring using Buckley's general model by setting the protein growth rate to zero and solving for RNA/DNA ratio at the temperature at which they captured the larvae. Rooker \& Holt (1996) suggested that caution be exercised when applying this ratio to new species in field studies due to the inherent developmental variation seen in RNA/DNA ratios of many species of marine teleost larvae.

A solution to this problem is to calculate for each species, under controlled conditions, the mean RNA/ DNA ratios of larvae deprived of food. In previous studies, this kind of calibration was done only with fed and starved laboratory-reared larvae (Buckley 1984, Clemmesen 1987, Robinson \& Ware 1988, Pittman 1991, Chícharo 1993). The results of such studies should be regarded with caution as laboratory conditions hardly simulate natural conditions (Blaxter 1976, Theilacker 1980a, Mackenzie et al. 1990. Folkvord \& Mokness 1995). Chícharo's studies $(1996,1997)$ made it possible to assess from a field experiment the RNA/ DNA ratio indicative of starvation in Sardina pilchardus (RNA/DNA ratios less than 1.3).
Recent studies have advocated caution in the use of RNA/DNA ratios because the techniques used to determine them have either been faulty (McGurk \& Kusser 1992, Grémare \& Vétion 1994, Canino \& Calderone 1995, Suthers et al. 1996) or have lacked sufficient sensitivity (Bergeron et al. 1991, Richard et al. 1991, Mathers et al. 1994). Other workers have advocated caution in the use of ratios to remove the allometric effect of size and they have advised the use of a residual-based index from RNA content and an independently determined variable such as standard length or dry weight (Suthers et al. 1996). In addition, Houlihan (1991) and Mathers et al. (1994) have questioned the use of this index for calculation of instantaneous growth, since they found no correlation between RNA concentration and protein growth rate. Nevertheless, strong correlations between RNA/DNA and growth have been observed in a variety of species. such as Ciupea harengus, Ammodyles sp., Theragra chalcogramma, Paralichthys dentatus, Pseudopleuronectes americanus, Gadus morhua, Scomber scombrus and Morone saxatilis (Buckley 1984). One aspect which has not been subject to a morc detailed study is the diel variation of this index, which if such a fluctuation can be demonstrated, can also constitute an important limitation on the interpretation of results.

The first aim of this study was to determine the variation of the RNA/DNA ratios and the incidence of starvation among field-caught Sardina pilchardus larvae, in 2 hydrographic areas of the Cantabrian Sea (Bay of Biscay) over the period March to June 1992. In addition, we compared the zooplankton biomass with the RNA/DNA ratios in order to analyse the influence of prey availability on larval condition. Finally, variation in the nucleic acid indices at different hours of the day among S. pilchardus larvae caught throughout the spawning season was investigated.

\section{MATERIALS AND METHODS}

Field study. During 1992 four research cruises were carried out covering the main spawning season of sardine off the north coast of Spain, which occurs from March to June. Thus, the northern Spanish continental shelf $\left(45^{\circ}\right.$ to $42^{\circ} \mathrm{N}, 10^{\circ}$ to $\left.2^{\circ} \mathrm{W}\right)$ was sampled aboard the B/O 'Cornide de Saavedra' (6 to 20 March and 2 to 14 April 1992), the RV 'Valdivia' (4 to 24 May 1992) and the RRS 'Challenger' (23 May to 10 June 1992). The survey grid was divided into 2 areas: Area 1 , from the boundary with French territorial waters to near Gijon; and Area 2, from the boundary with Area 1 to Cape Ortegal (Fig. 1). In situ temperature determinations were carried out by a CTD (conductivity/ temperature/depth profiler) cast at selected stations. 


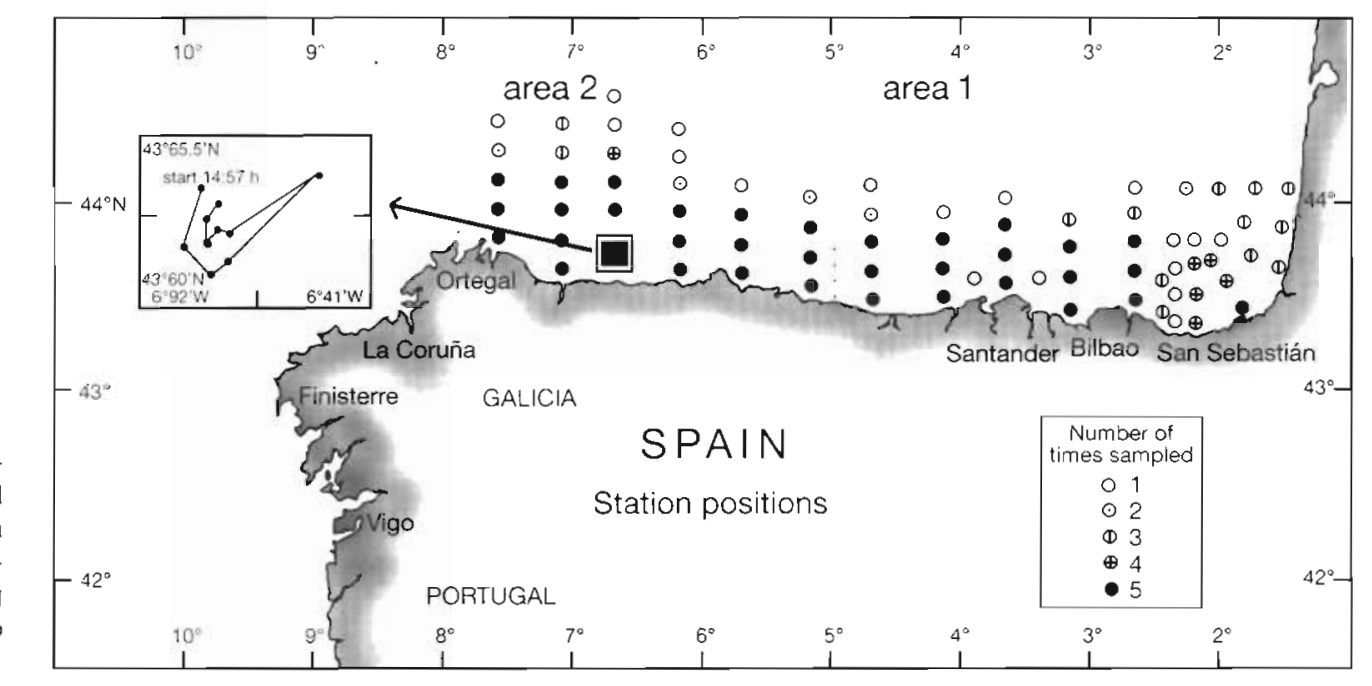

Fig. 1. Location of sampling areas, stations and sampling (ם). The number of cruises sampling stations from March to June 1992 shown cruise tracks for the $40 \mathrm{~h}$

Mesozooplankton tows (including sardine larvae) were double oblique, with a bongo $200 \mu \mathrm{m}$ mesh net (diameter $50 \mathrm{~cm}$ ), while zooplankton tows were double oblique, with a $53 \mu \mathrm{m}$ mesh net (diameter $10 \mathrm{~cm}$ ). Bongo net hauls were designed to sample to about $100 \mathrm{~m}$ depth or to about $10 \mathrm{~m}$ from the bottom in the more shallow areas. On completion of the mesozooplankton haul, coarse mesh samples were immediately sorted for the bulk of sardine larvae and stored in liquid nitrogen $\left(-196^{\circ} \mathrm{C}\right)$ for later RNA/DNA analysis. At each station a zooplankton sample was preserved in $4 \%$ buffered formaldehyde solution for taxonomic counts and another was frozen $\left(-20^{\circ} \mathrm{C}\right)$ for biomass estimation. In Area 2, where the highest concentration of sardine larvae had been found, a special drift sampling to investigate the day-night condition of the larvae was carried out for $40 \mathrm{~h}$ (Fig. 1). During this $40 \mathrm{~h}$ sampling, 11 bongo net hauls were made with a minimum interval of $2 \mathrm{~h}$ and a maximum interval of $7 \mathrm{~h}$.

Laboratory procedures. To determine the zooplankton biomass, samples were rinsed with an isotonic ammonium formate solution and heat dried to a constant weight in an electric oven at $60^{\circ} \mathrm{C}$. The results were expressed as dry weight ( $\mathrm{mg} \mathrm{DW} \mathrm{m}^{-3}$ ).

Before the nucleic acids were determined, standard lengths (SL) of thawed sardine larvae were measured under a dissecting microscope using an ocular micrometer. These lengths were corrected for shrinkage in the net according to Theilacker (1980b) and in the liquid nitrogen, using the following relationship:

FrozenSL $=0.422+0.92 \times$ FreshSL $(\mathrm{R}=0.87, \mathrm{n}=60)$

This relationship was derived from an experiment conducted off southern Portugal during 1992 in which fresh length and frozen length were measured on the same fish larvae.
In this study, nucleic acids were extracted from whole body Sardina pilchardus by homogenising the larvae for $1 \mathrm{~min}$ in $600 \mu \mathrm{l}$ ice-cold tris buffer containing sodium dodecyl sulphate (SDS, final concentration $1 \%$ ), using a sonicator. A highly sensitive fluorometric method for RNA/DNA quantification in individual organisms was applied.

Our analytical procedure was adapted from the methodology presented by Clemmesen (1988, 1990) for fish larvae, which allows individual larval analysis. It involves purification of tissue homogenates and subsequent fluorescence-photometric measurements using ethidium bromide (EB), a specific nucleic acids fluorochrome dye. The fluorescence due to total RNA. (mainly ribosomal) can then be calculated as the difference between total fluorescence (RNA and DNA) and the fluorescence after ribonuclease A (type II-A) treatment, which is assumed to be due to DNA. The fluorescence was determined by exciting at $365 \mathrm{~nm}$ and reading at $590 \mathrm{~nm}$ with a spectrofluorometer (Hitachi model 650-10j. Concentrations of nucleic acids were determined by running standard curves of DNA and RNA with EB every day, with known concentrations of calf thymus DNA and yeast RNA, in the appropriate range of values. Average recovery of added calf thymus DNA to larval samples (DNA spike) was $92.1 \pm$ $4.6 \%$ and average recovery of added yeast RNA (RNAspike) was $95.3 \pm 3.4 \%$. Total amounts of DNA and RNA in the post-larvae were corrected based on these average recovery efficiencies. The limit of detection (the analyte concentration giving a signal equal to the blank signal plus 2 standard deviations of the blank) was $0.1 \mu \mathrm{g} \mathrm{ml}^{-1}$ for DNA and $0.4 \mu \mathrm{g} \mathrm{m}^{-1}$ for RNA. The coefficient of variability (sample standard deviation as percentage of the mean) was $4 \%$ for DNA and $10 \%$ for RNA when 10 aliquots of tissue homogenate were measured. 
Starvation percentages. Larvae collected during the cruises with a RNA/DNA ratio equal to or below 1.3 were classified as starving. This value is the mean RNA/DNA ratio of sardine larvae obtained from an in situ experiment conducted off the coast of southern Portugal during 1992 (Chicharo 1996, 1997) in which larvae were deprived of food, inside net containers of $10 \mathrm{~m}$ mesh size, for 2 to $6 \mathrm{~d}$. In this experiment Sardina pilchardus larvae ranged from 5.5 to $12.3 \mathrm{~mm}$, and during the experiment daily measurements of water temperature were made (mean water temperature $15.3^{\circ} \mathrm{C}$ ).

Analysis. The effects of time of year (cruises), areas and night and day 107:00 to 20:00 $\mathrm{h}$, day; 20:00 to 07:00 h, night) on RNA/DNA ratios were examined by 3-way ANOVA. These effects on standard larval length were examined by a Kruskal-Wallis test (nonparametric ANOVA), due to the absence of normality. An index of condition was derived from the residuals of an overall, simple regression of $\ln (R N A+1)$ on $\ln (S \bar{L})$, according to Suther et al. (1996).

Using pooled samples (several larvae for each hour), the effect of time of day (hour) on RNA/arvae, DNA/larvae, SL, RNA/DNA and on the residuals of the 1 egression of RNA on SL was examined by a conventional 1 -way ANOVA with time of day as a categorical variate. As more than 2 comparisons were made, this analysis was followed by Tukey's test for comparison of means to compare means between hours, and the results were displayed on a graph. The relationships between RNA/DNA and zooplankton biomass were analysed by Pearsons' correlation (Snedecor \& Cochran 1989).

\section{RESULTS}

\section{Oceanographic conditions}

Between March and June 1992 ('Cornide', 'Valdivia' and 'Challenger' cruises) surface $(5 \mathrm{~m})$ water temperature ranged from 11.7 to $18.7^{\circ} \mathrm{C}$. In March and April ('Cornide' cruises) a slight temperature gradient was present from east to west, with cooler $\left(<12.5^{\circ} \mathrm{C}\right)$ water in the east (Area 1) and warmer water $\left(>13^{\circ} \mathrm{C}\right)$ in the west (Area 2). In May ('Valdivia' cruise) surface water temperature was higher than $14^{\circ} \mathrm{C}$ over most of the areas except the coastal zone, halfway between Gijon and Ortegal, where surface temperatures were near $13^{\circ} \mathrm{C}$ (Lopez-Jamar et al. 1995). The lower surface temperature in this area is an indication of upwelling of deep cooler water, which starts at about this time of year and usually continues until the end of summer (Robles et al. 1992). From the end of May ('Challenger' cruise), a marked warming of surface water took place; the highest surface temperatures were recorded to the west of Bilbao (>17.5 $\mathrm{C}$ ) (Lopez-Jamar et al. 1995).
Surface water salinity $(5 \mathrm{~m})$ in the study area generally ranged between 34.8 and 36.2 PSU, with lower values in the more eastern area (Area 1). Stratification values $\left(\Delta \sigma_{t} 0-50 \mathrm{~m}\right)$ were weak in March and April, indicating a well-mixed water column in the entire area, at least down to a depth of $50 \mathrm{~m}$. By May stratification was relatively pronounced in the eastern area, mainly in the more inshore region. The remainding area showed moderate stratification except off northwest Galicia, where a well-mixed water column was present, indicative of upwelling. From late May and June a similar stratification pattern was maintained, but the area of highly stratified water in the eastern area became more extensive (Lopez-Jamar et al. 1995).

\section{Zooplankton biomass (potential prey)}

The mean zooplankton biomass nuedsured at the stations where sardine larvae were analysed biochemically was compared among time of the year (cruises) and areas. The results revealed higher values during March and April ('Cornide' cruises), but the values were not significantly different from those found in the other months (May and June $\mathrm{p}<0.544$ ). When this parameter was compared between areas, the results indicated higher values for Area 1, but again the values were not significantly different from the other area $(\mathrm{p}<0.769)$.

Maximum biomass of zooplankton was recorded especially during the night (Area 2, 'Cornide' cruises; Area 1, 'Challenger' cruise) (Table 1). During the diurnal cycle, the maximum biomass of zooplankton was also recorded during the dark hours, with lower values occurring during the day (Table 1).

\section{Distribution and length of sardine larvae}

Sardina pilchardus were caught throughout most of the area under investigation. During March and May the highest concentrations (ranging to 100 to 150 larvae $\mathrm{m}^{-2}$ ) were distributed along the northern coast of Spain to the east of Cape Ortegal. In April, the highest larval abundance was recorded off Santander. Abundance of sardine larvae decreased drastically along the west coast of Spain, where especially the outer shelf stations frequently yielded zero larvae (Lopéz-Jamar et al. 1995)

The mean SL of field-caught larvae biochemically analysed ranged between 8 and $18 \mathrm{~mm}$. When the total larval lengths were analysed, significant differences were observed between nighttime and daytime using the non-parametric Kruskal-Wallis test $H(\mathrm{df}=1, \mathrm{n}=474=$ $4.414, p<0.036$ ). During the $40 \mathrm{~h}$ sampling as well the 
Table 1. Mean and standard deviation of the RNA/DNA ratios, standard length, zooplankton biomass by time of year (cruise) and area, during daytime and nighttime periods (n: number of larvae analysed or number of stations for zooplankton biomass measurements). Data for the 40 h sample are also included in the 'Valdivia' data

\begin{tabular}{|c|c|c|c|c|c|c|c|c|c|c|c|c|c|}
\hline Cruise & & $\mathrm{n}$ & $\begin{array}{c}\text { RNA/DNA } \\
\text { Area } 1\end{array}$ & n & $\begin{array}{c}\text { RNA/DNA } \\
\text { Area } 2\end{array}$ & $\mathrm{n}$ & $\begin{array}{l}\text { Length } \\
\text { Area } 1\end{array}$ & $n$ & $\begin{array}{l}\text { Length } \\
\text { Area } 2\end{array}$ & & $\begin{array}{c}\text { Zooplankton } \\
\text { biomass } \\
\text { Area } 1\end{array}$ & $n$ & $\begin{array}{c}\text { Zooplankton } \\
\text { biomass } \\
\text { Area } 2\end{array}$ \\
\hline 'Cornide' & Day & 30 & $2.77 \pm 0.51$ & 20 & $4.15 \pm 1.13$ & 30 & $10.6 \pm 2.0$ & 20 & $15.4 \pm 3.4$ & 2 & $5.04 \pm 0.2$ & 2 & $5.18 \pm 2.63$ \\
\hline Mar/Apr & Night & 29 & $2.75 \pm 1.03$ & 11 & $5.48 \pm 1.01$ & 29 & $12.9 \pm 4.1$ & 11 & $14.8+2.1$ & 3 & $4.68 \pm 1.94$ & 1 & 15.69 \\
\hline 'Valdivia' & Day & 42 & $3.89 \pm 1.65$ & 160 & $3.40 \pm 1.28$ & 42 & $19 \pm 3.6$ & 160 & $11.4 \pm 2.9$ & 3 & $2.77 \pm 0.52$ & 15 & $4.76 \pm 2.48$ \\
\hline May & Night & 26 & $3.76 \pm 1.59$ & 107 & $3.81 \pm 1.43$ & 26 & $11.1 \pm 3.6$ & 107 & $12 \pm 3.6$ & 5 & $7.38 \pm 2.49$ & 10 & $5.2 \pm 4.24$ \\
\hline 'Challenger' & Day & 16 & $3.53 \pm 1.24$ & 14 & $2.73 \pm 0.87$ & 16 & $11.6 \pm 2.8$ & 14 & $13.1 \pm 3.6$ & 3 & $3.96 \pm 2.71$ & 3 & $3.93 \pm 1.96$ \\
\hline Jun & Night & 5 & $4.28 \pm 1.69$ & 14 & $3.17 \pm 1.09$ & 5 & $12.6 \pm 1.1$ & 14 & $13.2 \pm 2.1$ & 1 & 12.75 & 1 & 4.61 \\
\hline \multirow[t]{2}{*}{40 h sample } & Day & & & 81 & $3.71 \pm 1.47$ & & & 81 & $11.6 \pm 2$ & & & 6 & $6.45 \pm 3.02$ \\
\hline & Night & & & 62 & $4.09 \pm 1.39$ & & & 62 & $12.7+2.5$ & & & 5 & $7.05 \pm 5.55$ \\
\hline \multirow[t]{2}{*}{ Total } & Day & 88 & $3.44 \pm 1.38$ & 194 & $3.43 \pm 1.27$ & 88 & $10.5 \pm 3.1$ & 194 & $11.9 \pm 3.2$ & 8 & $3.78 \pm 1.76$ & 20 & $4.68 \pm 2.33$ \\
\hline & Night & 60 & $3.32 \pm 1.45$ & 132 & $3.87 \pm 1.43$ & 60 & $12.1 \pm 3.8$ & 136 & $12.4 \pm 3.4$ & 9 & $7.08 \pm 3.21$ & 12 & $6.02 \pm 4.9$ \\
\hline
\end{tabular}

larger larvae were captured mainly at night (Fig. 2). Significant differences in length were also observed among areas, $H(\mathrm{df}=1, \mathrm{n}=474=11.446, \mathrm{p}<0.003)$, and among times of year, $H(\mathrm{df}=2, \mathrm{n}=474=8.414, p<0.015)$.

\section{Starvation percentages}

The starvation percentages were generally low. The highest value, $3.23 \%$, was observed during the earliest cruises in March and April ('Cornide' cruises) in Area 2

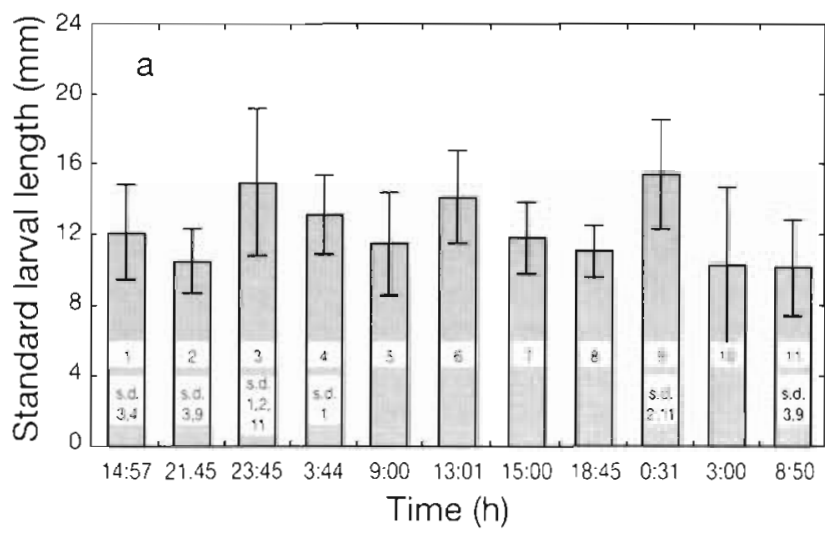

Fig. 2. Change in (a) average standard length, (b) average $\mu \mathrm{g}$ RNA larvae ${ }^{-1}$ and (c) average residual of $\ln (\mathrm{RNA}+1)$ on In(standard length) of Sardina pilchardus larvae over the $40 \mathrm{~h}$ sampling. Error bars are standard errors. Number in each bar shows the significant differences (s.d.) between hours, results of Tukey's test $(p<0.05)$, which was done using 1-way ANOVA, with significant $F$ (Table 4 ). The number of larvae analysed/captured in each tow was: $14: 57 \mathrm{~h}(12 / 264), 21: 45 \mathrm{~h}$ (18/150), 23:45 h (13/384), 03:44 h (10/461), 09:00 h (11/349), $13: 01 \mathrm{~h}(10 / 171), 15: 00 \mathrm{~h}(19 / 157), 18: 45 \mathrm{~h}(11 / 551), 00: 31 \mathrm{~h}$ $(12 / 382), 03: 00 \mathrm{~h}(10 / 382), 08: 50 \mathrm{~h}(17 / 290)$
(Table 2). Values near zero were found for the cruises in May and June ('Valdivia' and 'Challenger' cruises).

\section{Nutritional condition}

This study measured the nucleic acid content of 474 sardine larvae, 90 during the 'Cornide' cruises (March and April), 335 during the 'Valdivia' cruise (May) and 49 during the 'Challenger' cruise (May-June). Among other things, a $40 \mathrm{~h}$ sampling was performed and 143
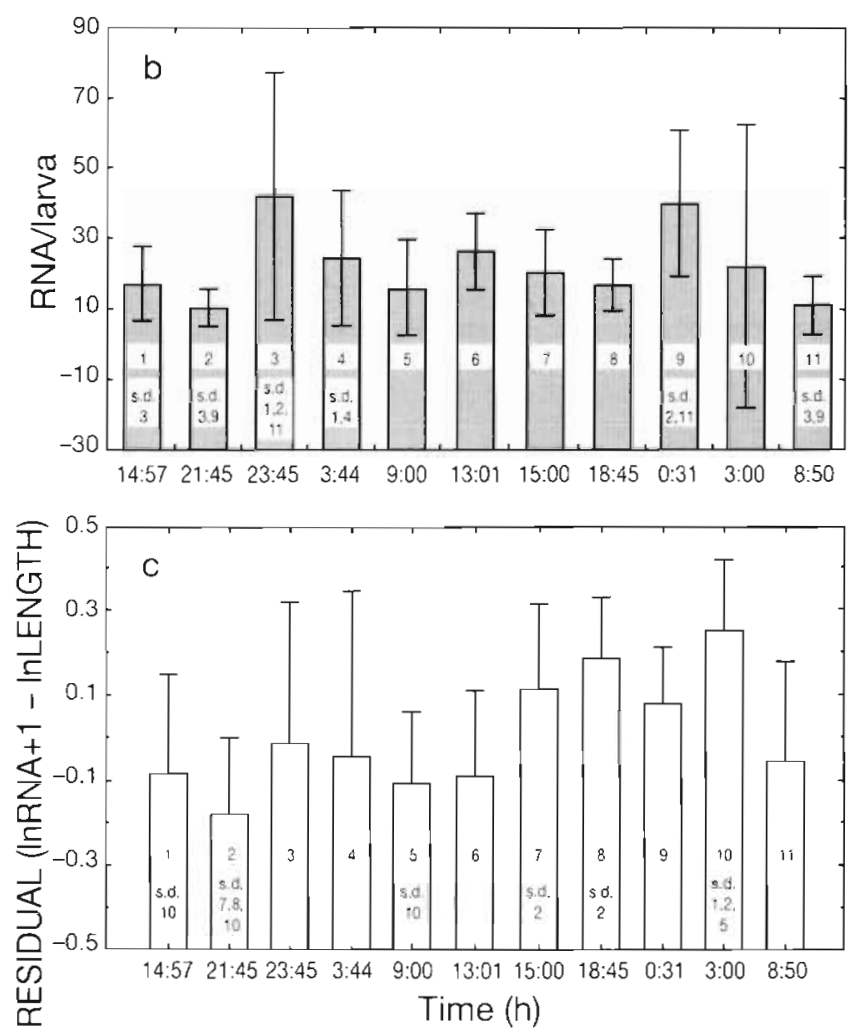
Table 2. Starvation percentages by time of year (cruises in March-April, May and June) and area $(1,2)$. Percentages below are number of larvae with RNA/DNA ratio $<1.3$ and total number of larvae analysed

\begin{tabular}{|lcccc|}
\hline Area & Mar/Apr & May & Jun & Total \\
\hline 1 & $1.7 \%$ & $0 \%$ & $0 \%$ & $2.03 \%$ \\
& $(1 / 59)$ & & & $(3 / 148)$ \\
2 & $3.23 \%$ & $0.75 \%$ & $0 \%$ & $0.3 \%$ \\
& $(1 / 31)$ & $(2 / 267)$ & & $(1 / 326)$ \\
Total & $0.6 \%$ & $0.6 \%$ & $0 \%$ & $1.07 \%$ \\
& $(2 / 90)$ & $(2 / 335)$ & & $(4 / 474)$ \\
& & & & \\
\hline
\end{tabular}

larvae were analysed during the 'Valdivia' cruise. The number of sardine larvae analysed was dependent on the quantity immediately frozen after capture in each cruise and zone.

The average values of RNA/DNA ratio were relatively high, but during March-April ('Cornide' cruises) and in Area 2 the mean values of these indices were the highest (Table 1).

Average RNA/DNA ratio values were higher during the night than during the day, especially in Area 2 (Table 1). The effects of day and night hours, time of year (cruises) and areas on RNA/DNA ratios examined by a 3-way ANOVA indicated that the effect of day and night hours was the only one with a significant $F$ $(p<0.011)$. Significant values were also found for the interaction between cruise and area $(p<0.001)$ (Table 3). During the drift investigation, significant differences were found between the average RNA/DNA ratios of some hours $(p<0.0001)$ (Table 4$)$. The 1 -way ANOVA followed by the Tukey test ( $<<0.05$ ) (Fig. 3), revealed that at times such as at 18:45 h (twilight) or 03:00 h (night) the means of RNA/DNA ratios were significantly different from the means at other times of day (Fig. 3). The RNA concentration also was shown to have higher values at night (23:45 and 00:31 h) (Fig. 2).

Table 3. Summary of a 3-way ANOVA for combined data fixed effect of RNA/DNA: 1 = cruise, 2 = area, 3 = day/night (07:00 to $20: 00 \mathrm{~h}$, day; 20:00 to $07: 00 \mathrm{~h}$, night). Ind. var.. independent variable; $\mathrm{df}$ : degrees of freedom; MS: mean square $\cdot p<0.05$

\begin{tabular}{|lcrrrrr|}
\hline Ind. var. & $\begin{array}{c}\text { df } \\
\text { effect }\end{array}$ & $\begin{array}{c}\text { MS } \\
\text { effect }\end{array}$ & $\begin{array}{c}\text { df } \\
\text { error }\end{array}$ & $\begin{array}{c}\text { MS } \\
\text { error }\end{array}$ & $F$ & p-level \\
\hline 1 & 2 & 1.82 & 462 & 1.694 & 1.074 & 0.342 \\
2 & 1 & 4.454 & 462 & 1.694 & 2.629 & 0.106 \\
3 & 1 & 11.081 & 462 & 1.694 & 6.541 & 0.011. \\
1,2 & 2 & 44.367 & 462 & 1.694 & 26.19 & $0.001 \cdot$ \\
1,3 & 2 & 2.297 & 462 & 1.694 & 1.356 & 0.259 \\
2,3 & 1 & 3.554 & 462 & 1.694 & 2.098 & 0.148 \\
$1,2,3$ & 2 & 2.344 & 462 & 1.694 & 1.384 & 0.252 \\
\hline
\end{tabular}

Table 4. Summary of a 1 -way ANOVA, fixed effect for 40 h sampling, with hours as independent variable. Dep. var.: dependent variable; $\mathrm{df}$ : degrees of freedom; MS: mean square

\begin{tabular}{|lcccllll|}
\hline Dep.var. & $\begin{array}{c}\text { df } \\
\text { effect }\end{array}$ & $\begin{array}{c}\text { MS } \\
\text { effect }\end{array}$ & $\begin{array}{c}\text { df } \\
\text { error }\end{array}$ & $\begin{array}{c}\text { MS } \\
\text { error }\end{array}$ & $F$ & p-level \\
\hline Length & 10 & 46.258 & 132 & 7.792 & 5.937 & 0.0001 \\
DNA/larvae & 10 & 88.307 & 132 & 14.911 & 5.922 & 0.0001 \\
RNA/larvae & 10 & 1480.4 & 132 & 342.726 & 4.32 & 0.0001 \\
Residual RNA & 10 & 0.227 & 132 & 0.050 & 4.502 & 0.0001 \\
RNA/DNA & 10 & 8.695 & 132 & 1.576 & 5.519 & 0.0001 \\
& & & & & & \\
\hline
\end{tabular}

To prevent length from influencing RNA/DNA ratios, the mean residual condition (residuals of RNA on SL) was used, but it showed a trend similar to the RNA/DNA (Fig, 2c)

The general correlation between the RNA/DNA ratıo and larval length was not significani $i r^{2}=0.052$; $p<0.093 ; n=474$ ), and similar results were found for drift sampling $\left(\mathrm{r}^{2}=0.023, \mathrm{p}<0.665 ; \mathrm{n}=143\right)$. Zooplankton biomass was related to the nutritional condition of fish larvae. During normal cruises zooplankton biomass explained $17 \%$ of the observed variability $\left(r^{2}=0.17 ; p<0.002 ; n=49\right)$ (Fig. 4a). Moreover, when drift sampling data was considered on its own, a significant correlation between RNA/DNA ratios and zooplankton biomass was also evident $\left(\mathrm{r}^{2}=0.442 ; \mathrm{p}<0.026\right.$; $\mathrm{n}=11$ ) (Fig, 4b), but in this case variation was explained to a high degree $(44 \%)$.

To discern the influence of zooplankton prey on RNA/DNA ratios of sardine larvae, the residuals of the relationship between zooplankton biomass and RNA/DNA ratios were analysed by time of the drift sampling and the results also show high values during the night hours (Fig. 5).

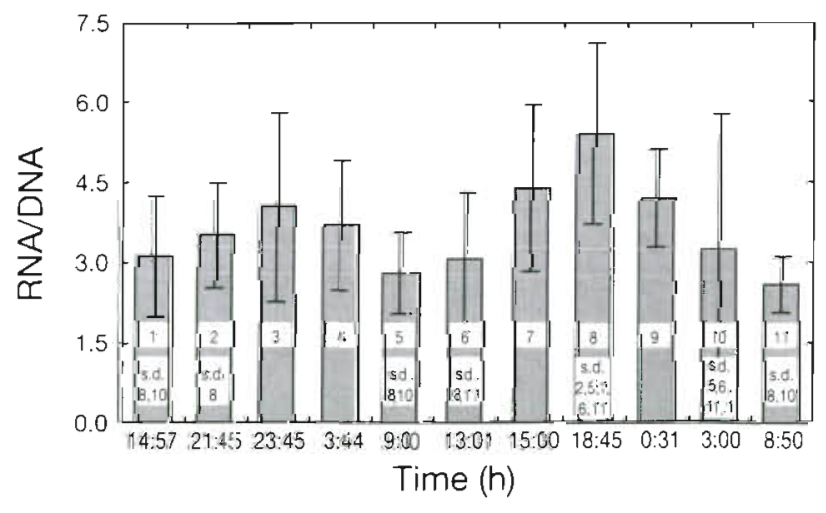

Fig. 3. Change in average RNAVDNA ratios of Sardina pilchardus larvae during the $40 \mathrm{~h}$ sampling. Error bars are standard error. Number in each bar shows the significant differences (s.d.) between hours, results of Tukey's test $(p<0.05)$, which was done using 1 -way ANOVA, with significant $F$ (Table 4) 

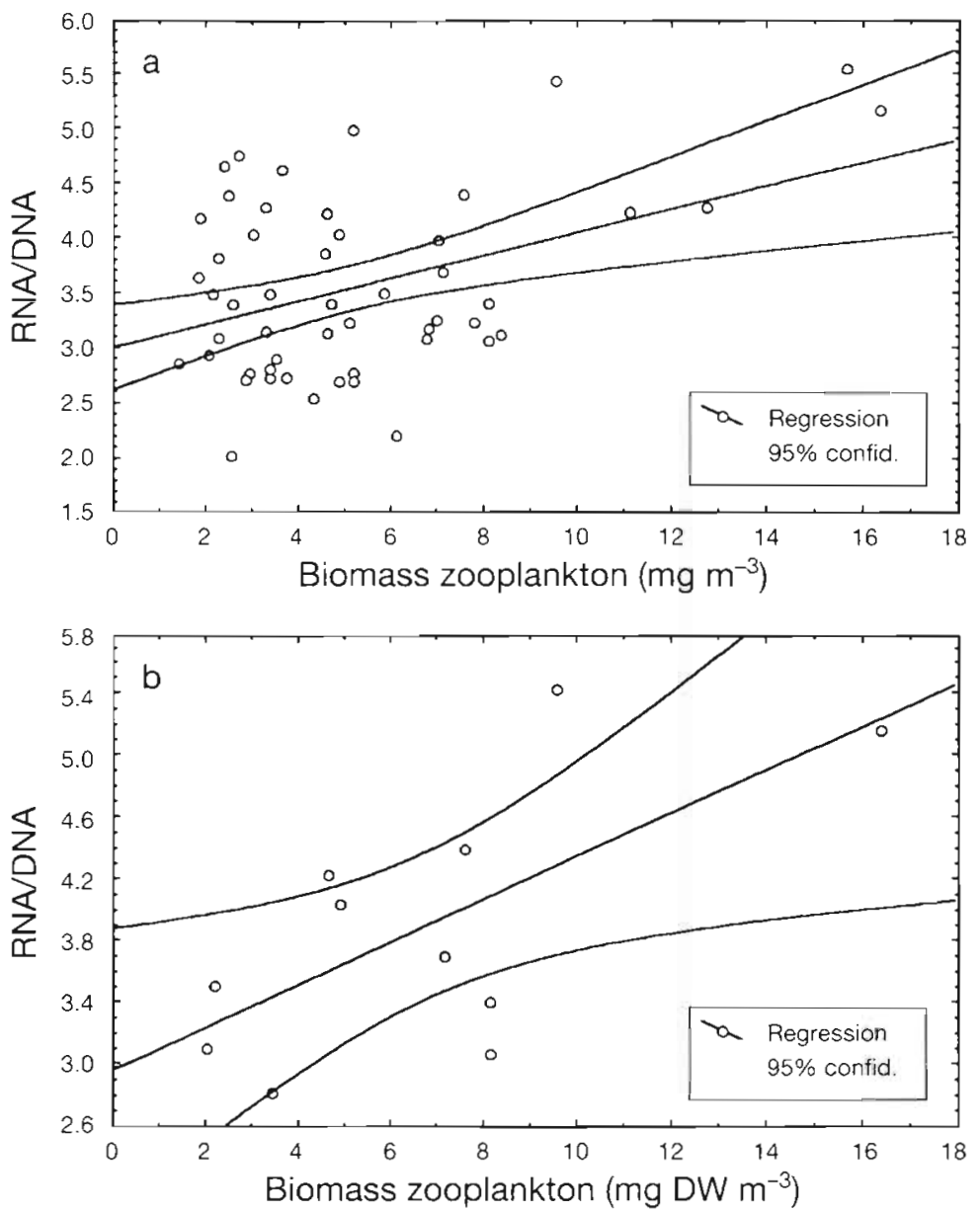

Fig. 4. Relationship of RNA/DNA on zooplankton biomass: (a) total cruises; (b) $40 \mathrm{~h}$ sampling data. DW: dry weight

\section{DISCUSSION}

\section{Starvation and nutritional condition}

To assess the importance of starvation for fieldcaught larvae it is necessary to determine the RNA/ DNA ratio below which larvae are classified as starving. Until now, this kind of calibration has been done only in laboratory conditions (Buckley 1984, Clemmesen 1987, Robinson \& Ware 1988, Pittman 1991, Chícharo 1993), which hardly simulate natural conditions (Blaxter 1976, Theilacker 1980, Mackenzie et al. 1990, Folkvord \& Mokness 1995). Chícharo's studies (1996, 1997) made it possible to assess from a field experiment the RNA/DNA ratio indicative of starvation in Sardina pilchardus (RNA/DNA ratios less than 1.3).

The utilisation of the mean RNA/DNA ratio obtained from starved fish larvae to determine starvation percentage has some problems. In fact, the RNA/DNA ratio is temperature dependent and also seems to change with larval size. These are important limitations because when we work with field samples the variability of temperatures and larval size is usually high. However, despite the wide range of water temperatures measured during this study $\left(11.7\right.$ to $\left.18.7^{\circ} \mathrm{C}\right)$, the great majority of samples were taken during May, when water temperature was close to the water temperature during the field experiment $\left(15.3^{\circ} \mathrm{C}\right)$.

The range of larval length studied in the field experiment was 5.5 to $12.3 \mathrm{~mm}$ (Chicharo 1997) and bigger larvae (8 to $18 \mathrm{~mm}$ ) were found in the sea. Thus, if this ratio increases with age (length) (Clemmesen 1994, Rooker \& Holt 1996), we could be stating that some starved larvae are in good condition. Nevertheless, according to Clemmesen (1994) the increase in the RNA/DNA ratio with length was less pronounced in starving larvae compared to fed larvae. Also, if we increase our ratio (1.3; Chícharo 1997) to 1.5 [the ratio Clemmesen (1994) gave for a starved herring larvae $18 \mathrm{~mm}$ in length], the same starvation percentages are obtained.

Only $0.84 \%$ (4/474) of sardine larvae collected during this study were classified as starving. This result is lower than that found for sardine larvae $(4.8 \%)$ collected on the Algarve continental shelf (southern Portugal) during May 1992 (Chícharo 1997). In addition, there are few reports of finding larvae in poor condition at sea. Since the initial studies of larval condition conducted by Ehrlich et al. (1976) and O'Connell (1976, 1980), who showed evidence that only $8 \%$ of wild Clupea harengus larvae were in condition of starvation, many other studies have confirmed those results. Buckley

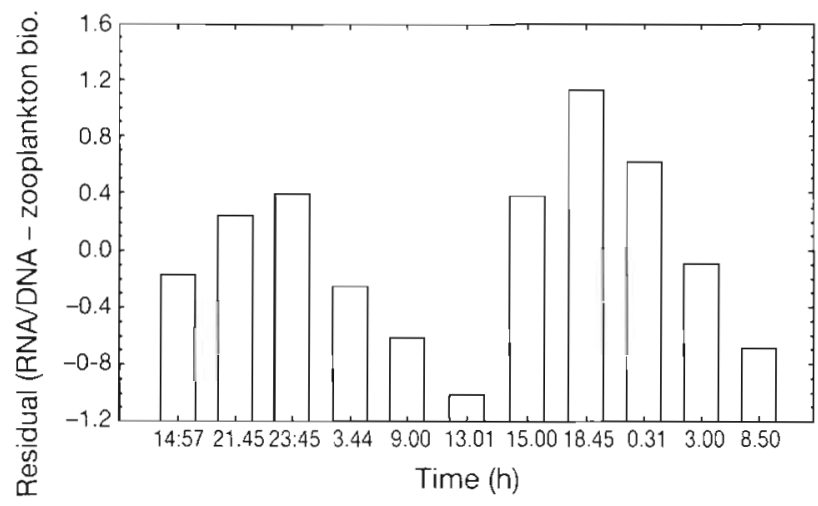

Fig. 5. Change in average residual of RNA/DNA ratios on zooplankton biomass $\left(\mathrm{mg} \mathrm{m}^{-3}\right)$ during the $40 \mathrm{~h}$ sampling 
(1984) found 2 and $7 \%$ of starved larvae of Melanogrammus aeglefinus and Ammodytes sp., respectively. Clemmesen (1994) found only $1 \%$ of $C$. harengus larvae with RNA/DNA ratios below the critical level. Meanwhile, McGurk et al. (1992) detected $8 \%$ of starved larvae of the same species, but in a different area. Thus, the percentage of larvae in poor condition may vary between taxa, study area and over time. In fact, the results of the present study indicate some variability of starving larvae between areas and months (cruises).

The highest starvation percentages were found in Area 2 and during the months of March and April. Surprisingly, the mean value of zooplankton biomass was highest during this period and in this area. This result was probably related to the well-mixed column in the area. However, the highest starvation percentages determined in such conditions may be related to the existence of some abnormal larvae. According to McGurk et al. (1992), there are larvae which may not have successfully developed their feeding abilities and are therefore not able to take advantage of food availability.

The general condition of sardine larvae, measured by the RNA/DNA ratio during the sampling period, was very good. Complementary findings are summarised by McFadzen et al. (1997) for measurements of larval condition (histological methods) and by Conway et al. (1994) for measurements of sardine larvae feeding which were made on the same cruises. The first study showed that most specimens were in medium or good condition and the second suggested, based on the quantity of food in the guts of larvae, that in all months there was generally sufficient food available to the larvae. Moreover, in the present study, zooplankton biomass seems to explain part of the variation in RNA/DNA ratios which was revealed by the significant correlation between this index and the potential prey of sardine larvae. This seems to agree with several other recent studies, namely, Canino et al. (1991), Canino (1994), Bailey et al. (1995), Suthers (1996), and Suthers et al. (1996). However, results of sardine larval condition measured by histological methods (McFadzen et al. 1997), on the same cruises, indicated the lack of any overall correlation between food availability and the RNA/DNA index. It should be recognised that the measures of food availability in McFadzen et al.'s study were derived from estimates of food concentrations (number l') and in our study they were derived from biomass determinations

Relating starvation and larval condition to food availability in the plankton is complex due to small-scale temporal and spatial patchiness in the distribution of fish larvae and prey (Mackenzie \& Kiørboe 1995), Zooplankton concentration or biomass estimates may under- estimate prey availability when zooplankton production is being consumed as quickly as it is being produced (Hunter 1981). Sometimes it is difficult to distinguish between the influences of prey availability, which contribute to an enhanced condition, and the effects of predation, which may result in loss of weak larvae in the samples taken and also to an enhanced general condition of collected larvae (Bailey \& Houde 1989).

\section{Diel variation of nucleic acids}

Our results seem to indicate a significant diel effect for RNA/DNA, RNA residuals and RNA/larvae. In the nucleic acids indices, this kind of diel effect has not been reported very often in previous studies with fish larvae. In fact, Bailey et al. (1995) found no significant diel effect on RNA content using SL as covariate with Theragra chalcogramma larvae. However, with Scyaenops ocellatus larvae, Rooker \& Holt (1996) found diel changes in RNA/DNA ratios, with higher values during daytime periods and markedly reduced ratios at night. The results of a 3-way ANOVA (cruise, ared and day/night) on the general RNA/DNA ratios in the present study also suggested a significant diel effect, but higher values were found during the night in the present study. Also, when we analysed the variation during a diurnal cycle, the results suggested that at twilight and during early hours of the night RNA/DNA values were significantly higher. Thus, this difference may be a specific characteristic of this particular species.

Because larger individuals were found during the nightime in our study and because some authors (Suthers 1992, Clemmesen 1994, Rooker \& Holt 1996. Suthers et al. 1996) have argued that the RNA/DNA ratio increases with age, we tried to eliminate any vestiges of a length influence using the RNA residual indices. In fact, the absence of normally distributed length data showed that we were selecting size class. In any event, our study found no significant relationship between RNA/DNA ratios and length. When we analysed the variations of residual RNA on standard length during the $40 \mathrm{~h}$ sampling, similar RNA/DNA ratios were found, with somewhat higher values being noted during dark hours. This could be explained by the following hypothesis: an endogenous rhythm exists that raises the concentration of RNA in Sardina pilchardus larvae during certain hours. It is probably the case that circadian periodicities in endocrine activity are responsible for observed patterns. Circadian periodicities in cell division rate or in growth-regulating hormones has been reported for several eukaryotic organisms: algae (Makarov et al. 1995, Costas et al. 1996), insects (Zeng et al. 1996), rats and sheep (Coon 
et al. 1995) and marine fishes (Bates et al. 1989). In a study by Makarov et al. (1995), in marine macroalgae the majority of nuclear divisions took place during the dark period. In mammals the night-to-day ratio of melatonin, the hormone that co-ordinates daily and seasonal physiology, is less than 2 in sheep and exceeds 150 in rats (Coon et al. 1995). The light/dark regimen seems to induce a circadian protein synthesis rhythm in these organisms which is probably responsible for the diel variations in RNA/DNA ratios.

We excluded the hypothesis that a sudden increase in RNA concentration takes place in response to an increase in food availability because, firstly, according to Clemmesen (1994), the RNA/DNA ratios do not reflect increase in prey availability over a period of hours. In fact, a sudden increase in food availability at first leads to an increase in the activity of the ribosome followed later by an increase in their numbers. The methodology used measures only the ribosome content. Secondly, despite the increase in food availability at night most fish larvae do not feed at night (Suthers \& Sundby 1996). According to Conway et al. (1991), the diel variation in feeding incidence in Sardina pilchardus reveals lowest feeding incidence during the dark, between 20:00 and 04:00 h GMT. This observation applies equally well to most other species of fish (Last 1980, Suthers et al. 1996) and is related to the fact that fish larvae are visual feeders. However, the results of Conway et al. (1991) also suggest that, surprisingly, smaller larvae (<15 mm) show the least diurnal effect, maintaining almost the same feeding incidence throughout the day and the night. This contrasts with other observations (Arthur 1976) that clupeid larvae do not feed at night.

In the light of the foregoing observations, only one other hypothesis may be developed to try to explain the fact that RNA indices are higher during the night. This hypothesis assumes that the higher values result from the RNA of the prey, which remain in the sardine guts after the day's feeding activity. In fact, there were no differences in the mean number of food items per feeding larvae during daytime or nighttime hours, except during the period 20:00 to 24:00 h, when the highest value was recorded (Conway et al. 1991). However, the rapid digestion rate of larval prey (Arthur 1974) and the loss of gut contents through defecation that occurs in response to net capture and preservation (Colton et al. 1980, Blaxter \& Hunter 1982, Conway et al. 1991) make this hypothesis difficult to prove. Moreover, when we removed the influence of zooplankton biomass on RNA/DNA ratios, the residuals of RNA/ DNA ratios still revealed a periodic fluctuation.

Although it is still necessary to confirm under controlled conditions (constant light, temperature, etc.) the hypothesis that an endogenous rhythm exists, it can be concluded from the present study that, because of these diel changes in RNA concentrations, average RNA indices may be unrepresentative when there is a day/night bias in sampling.

Acknowledgements. This research was partially funded by the Commission of the European Communities (D.G.XIV) and by a grant (no. 30516) from the Instituto Nacional de lnvestigaçào Cientifica (INIC). Thanks are due to all persons that provided their data or participated in the cruises. We are grateful to Dr John Nascimento for his helpful remarks

\section{LITERATURE CITED}

Arthur DK (1976) Food and feeding of larvae of three fishes occurring in the California current, Sardinops sagax, Engraulis mordax, Trachurus symmetricus. Fish Bull US $74: 517-530$

Bailey KM, Canino MF, Napp JN, Spring SM, Brown AL (1995) Contrasting years of prey levels, feeding conditions and mortality of larval walleye pollock Theragra chalcogramma in the western Gulf of Alaska. Mar Ecol Prog Ser 119:11-23

Bailey KM, Houde ED (1989) Predation on eggs and larvae of marine fishes and the recruitment problem. In: Blaxter JHS, Southward AJ (eds) Advances in marine biology, Vol 25. Academic Press, London, p 1-83

Bates DJ, Barret BA, Mckeown BA (1989) Daily variations in plasma growth hormone of juvenile coho salmon, Oncorhynchus kisutch. Can J Zool 67:1246-1248

Bergeron JP, Boulhic M, Galois R (1991) Effet de la privation de nourriture sur la teneur en AND de la larve de sole (Solea solea L.). ICES J Mar Sci 48:127-134

Blaxter JHS (1976) Reared and wild fish - how do they compare? In: Persoone G, Jaspers E (eds) 10th Eur Symp Mar Biol, Vol 1. Universa Press, Wetteren, p 11-12

Blaxter JHS, Hunter R (1982) The biology of the clupeioid fishes. Adv Mar Biol 20:1-223

Buckley L (1984) RNA/DNA ratio: an index of larval fish growth in the sea. Mar Biol 80:291-298

Canino MF (1994) Effects of temperature and food availability on growth and RNA.DNA ratios of walleye pollock Theragra chalcogramma (Pallas) eggs and larvae. J Exp Mar Biol Ecol 175:1-16

Canino MF, Bailey K, McIncze LS (1991) Temporal and geographic differences in feeding and nutritional condition of walleye pollock larvae Theragra chalcogramma in Shelikof Strait, Gulf of Alaska. Mar Ecol Prog Ser 79:27-35

Canino MF, Caldarone EM (1995) Modification and comparison of two fluorometric techniques for determining nucleic acid contents of fish larvae. Fish Bull US 93:158-165

Chícharo MA (1993) Estado nutricional em larvas de peixe: análise de ácidos nucleicos e proteinas. Bol UCA U. Algarve, UCTRA 1:653-669

Chícharo MA (1996) Métodos de avaliação do estado nutricional em larvas de Sardina pilchardus aplicados ao estudo das condiçôes de sobrevivência no meio natural (Methods for the evaluation of the nutritional state of Sardina pilchardus larvae applied to the study of survival conditions in nature). $\mathrm{PhD}$ thesis, Univ Algarve

Chícharo MA (1997) Starvation percentages in field caught Sardina pilchardus larvae off southern Portugal. Sci Mar $61(4): 507-516$

Chícharo L, Chícharo MA (1995) The RNA/DNA ratio as a useful indicator of the nutritional condition in juveniles of 
Ruditapes decussatus. Sci Mar 59(Suppl 1):95-101

Clarke A, Rodhouse PG, Holmes LJ, Pascoe PL (1989) Growth rate and nucleic acid ratio in cultured cuttlefish, Sepia officinalis (Mollusca: Cephalopoda). J Exp Mar Biol Ecol $133: 229-240$

Clemmesen C (1987) Laboratory studies on RNA/DNA ratios of starved and fed herring (Clupea harengus) and turbot (Scophthalmus maximus). J Cons Int Explor Mer 43: $122-128$

Clemmesen C (1988) A RNA and DNA fluorescence technique to evaluate the nutritional condition of individual marine fish larvae. Meeresforsch 32:134-143

Clemmesen C (1990) Improvements in the determinations of RNA and DNA content in individual marine fish larvae. ICES CM Biol Oceanogr Comm 98, p 1-14

Clemmesen C (1994) The effect of food availability, age or size on the RNA/DNA of individually measured herring larvae: laboratory calibration. Mar Biol 118:377-382

Colton JB, Green J, Byron RR, Frisella JL (1980) Bongo net retention rates as effected by towing speed and mesh size. Can J Fish Aquat Sci 37:606-623

Conway DVP, Tranter PRG, Puelles MLF, Coombs SH (1991) Feeding of larval sprat (Sprattus sprattus L.) and sardine (Sardina pilchardus Walbaum). ICES CM Biol Oceanogr Comm 76, p 1-7

Conway DVP, Tranter PRG, Puelles MLF, Coombs SH (1994) Feeding of larval sardine (Sardina pilchardus Walbaum) off the north of Spain. Bol Inst Esp Oceanogr 10(2):165-175

Coon SL, Roseboom PH, Baler R, Weller JL, Namboodiri MAA, Koonin EV (1995) Pineal serotinin N-Acetyltransferase-expression on cloning and molecular analysis. Science 270(5242):1681-1683

Costas E, Gonzalezgil S, Lopezrodes V, Aguilera A (1996) The influence of slowing earths rotation-a hypothesis to explain cell division synchrony under different day duration in earlier and later evolved algae. Helgol Meeresunters 50(1):117-130

Cushing DH (1975) Marine ecology and fisheries. Cambridge University Press, Cambridge

Cushing DH (1990) Plankton production and year class strength in fish populations: an update of the match/mismatch hypothesis. Adv Mar Biol 26:249-293

Cushing DH (1995) A comment on Leggett \& DeBlois. Mar Ecol Prog Ser 128:305-310

Ehrlich KF, Blaxter JHS, Pemberton R (1976) Morphological and histological changes during the growth and starvation of herring and plaice larvae. Mar Biol 35:105-118

Folkvord A, Moksness E (1995) RNA/DNA ratios and growth of herring larvae. Mar Ecol Prog Ser 121:311-312

Grémare A, Vétion G (1994) Comparison of several spectrofluorimetric methods for measuring RNA and DNA concentrations in the deposit-feeding bivalve Abra ovata. Comp Biochem Physiol 107B(2):297-308

Hjort J (1914) Fluctuation in the great fishenes of northern Europe. Viewed in the light of biological research. Rapp Reun Cons Perm Explor Mer 20:1-228

Houlihan DF (1991) Protein turnover in ectotherms and its relationship to energetics. In: Gilles $R$ (ed) Advances in comparative and environmental physiology, Vol 7. Springer-Verlag, Berlin, p 1-43

Hunter JR (1981) Feeding ecology and predation of marine fish larvae. In: Lasker R (ed) Marine fish larvae: morphology, ecology and relation to fisheries, 2nd edn. Washington Sea Grant, Washington, p 34-40

Lasker R (1975) Field criteria for survival of anchovy larvae: the relation between inshore chlorophyll maximum layers and successful first feeding. Fish Bull US 73:453-462
Last JM (1980) The food of twenty species of fish larvae in the west-central North Sea. Fish Res Tech Rep MA.FF Direct Fish, Lowestoft 60

Leggett WC, DeBlois E (1994) Recruitment in marine fishes: is it regulated by starvation and predation in the egg and larval stages? Neth J Sea Res 32:119-134

Lopéz-Jamar, E, Coombs SH, Garcia A, Halliday NC, Knust R, Nellen W (1995) The distribution and survival of sardine, Sardina pilchardus, off the North and Northwest Atlantic Coast of Spain in relation to environmental conditions. BoI Inst Esp Oceanogr 11(1):27-46

Mackenzie BR, Kiørboe TK (1995) Encounter rates and swimming behaviour of pause-travel and cruise larval fish predators in calm and turbulent laboratory environments. Limnol Oceanogr 40(7):1278-1289

Mackenzie BR, Leggett WC, Peters RH (1990) Estimating larval fish ingestion rates: can laboratory derived values be reliably extrapolated to the wild? Mar Ecol Prog Ser 67:209-225

Makarov VN, Schoschina EV, Luning K (1995) Diurnal and circadian periodicity of mitosis and growth in marine macroalgae. Juvenile sprophytes of Laminariales (Phaeophyta). Eur J Phycol 30(4):261-266

Martin, FD, Wright DA (1987) Nutritional state analysis and its use in predicting striped bass recruitment: laboratory calibration. Am Fish Soc Symp 2:109-114

Mathers EM, Houlihan DF, Burren LJ (1994) RNA, DNA and protein concentrations in fed and starved herring Cluped harengus larvae. Mar Ecol Prog Ser 107:223-231

McFadzen I, Coombs SH, Halliday NC (1997) Histological indices of the nutritional condition of sardine Sardina pilchardus larvae off the north coast of Spain. J Exp Mar Biol Ecol 212:239-258

McGurk MD, Kusser W (1992) Comparison of three methods of measunng RNA and DNA concentrations of individual Pacific herring, Clupea pallasi, larvae. Can J Fish Aquat Sci 49:967-974

McGurk MD, Warburton HD, Galbraith M, Kusser WC (1992) RNA-DNA ratio of herring and sand lance larvae from Port Moller, Alaska: comparison with prey concentration and temperature. Fish Oceanogr 1(3):193-207

O'Connell C (1976) Histological criteria for diagnosing the starving condition in the early post yolk sac larvae of the northern anchovy, Engraulis mordax G. J Exp Mar Biol Ecol 25:285-312

O'Connell C (1980) Estimation by histological methods of the percent of starving larvae of the northern anchovy (Engraulis mordax) in the sea. Rapp PV Reun Cons Int Explor Mer 178:357-360

Parrish RH. Nelson CS, Bakun A (1981) Transport mechanisms and reproductive success of fishes in the California current. Biol Oceanogr 1(2):175-204

Pestana MG (1989) Manancial ibérico-atlântico de sardinha (Sardina pilchardus, Walb.) Sua avaliação e medidas de gestāo. Dissertação, Instituto Nacional de Investigaçāo Científica, Lisboa

Pittman K (1991) Aspects of the early life history of Atlantic halibut (Hippoglossus hippoglossus L.): embryonic and larval development and the effects of temperature. Dr Sci thesis, University of Bergen, Noruega

Porteiro C, A.lvaréz F, Pérez N (1986) Variaciones en el stock de sardina (Sardina pilchardus Walb.) de las costas atlanticas de la Peninsula Iberica (1976-1985). Int Symp LongTerm Changes Mai Fish Pop Vigo 1:529-541

Richard P, Bergeron JP, Boulhic M, Galois R, Le Ruyet JP (1991) Effect of starvation on RNA/DNA and protein content of laboratory-reared larvae and juvenile of Solea 
solea. Mar Ecol Prog Ser 72:69-77

Robinson SM, Ware D (1988) Ontogenetic development of growth rates in larval Pacific hermng, Clupea harengus pallasi, measured with RNA/DNA ratios in the Strait of Georgia, British Columbia. Can $J$ Fish Aquat Sci 45: 1422-1429

Robles R, Porteiro C, Cabanas JM (1992) The stock of AtlantoIberian sardine: possible causes of variability. ICES Mar Sci Symp 195:418-423

Rooker JR, Holt GJ (1996) Application of RNA-DNA ratios to evaluate the condition and growth of larvae and juvenile red drum (Sciaenops ocellatus). Mar Freshwat Res 4782: $283-290$

Setzler-Hamilton EM, Martin DA, Millsaps FD, Whitlow CV (1987) Analysis of nutritional condition and its use in predicting stripe bass recruitment: field studies. Am Fish Soc Symp 2:115-128

Snedecor G, Cochran W (1989) Statistical methods. Iowa State University Press, Ames

Suthers IM (1992) The use of condition indices in larval fish. Bureau Rural Resources Proc 15:49-55

Editorial responsibility: Otto Kinne (Editor),

Oldendorf/Luhe, Germany
Suthers IM (1996) Spatial variability of recent otolith growth and RNA indices in pelagic juvenile Diaphus kapalae (Myctophidae): an effect of flow disturbance near an Island? Mar Freshwat Res 47:273-283

Suthers IM, Cleary JJ, Battaglene SC, Evans R (1996) Relative RNA content as measure of condition in larval and juvenile fish. Mar Freshwat Res 47:301-307

Suthers IM. Sundby S (1996) Role of the midnight sun: comparative growth of pelagic juvenile cod (Gadus morhua) from the Arcto-Norwegian and a Nova Scotian stock. ICES J Mar Sci 53:827-836

Theilacker (il f (1980a) Rearing contanner size affects morphology and nutritional condition of larvae jack mackerel (Trachurus symmetricus). Fish Bull US 78(3):789-792

Theilacker GH (1980b) Changes in body measurements of larval northern anchovy, Engraulis mordax, and other fishes due to handling and preservation. Fish Bull US $78(3): 685-692$

Zeng HK, Qian ZW, Myers MP, Rosbash M (1996) A lightentrainment mechanism for the drosophila circadian clock. Nature 380(6570):129-135

Submitted: May 6, 1997; Accepted: January 9, 1998

Proofs received from author(s): March 6, 1998 